\title{
The Design and Evaluation of Mobile App- Supported Basketball Teaching: A Blended Learning Approach
}

\author{
Yingjie Zhang \\ Department of Physical Education, \\ Tsinghua University, \\ Beijing, China \\ zhyingjie@tsinghua.edu.cn
}

\author{
Yuping Wang* \\ School of Langugages, Humanities and \\ Social Science, \\ Griffith University, \\ Brisbane, Australia \\ y.wang@griffith.edu.au \\ *Corresponding author of the paper
}

\author{
Jiangang Cheng \\ Institute of Education, \\ Tsinghua University, \\ Beijing, China \\ chengjg@tsinghua.edu.cn
}

\begin{abstract}
This paper explores the course design and student satisfaction with a Chinese university basketball course offered in blended mode through the support of mobile technology. There are four parts to this study: (1) the design of a basketball course using the blended learning approach supported by flipped classrooms and a mobile app; (2) a 3week trial of this approach as a pilot study in the spring semester of 2017 ; (3) informed by this pilot study, a semesterlong implementation of the approach in the autumn semester of 2017; (4) an evaluation of students' satisfaction with this blended learning approach through the use of surveys. The results indicate that this approach to course design and delivery effectively facilitated student learning. The survey data further confirmed the students' satisfaction with this new learning and teaching approach as well as the course, as they believed that this approach had improved their learning quality, in-class interaction and learning outcomes in physical education.
\end{abstract}

Keywords—basketball, blended learning, flipped classrooms, student satisfaction, mobile learning, physical education

\section{INTRODUCTION}

Mobile learning, also known as M-learning, has become an outstanding feature of blended learning since the turn of the century. Mobile learning refers to a kind of learning supported by handheld mobile devices such as smartphones and IPad. Mobile technology has been used widely in supporting learning in different disciplinary areas because it offers flexibility, ubiquitousness and ease of access to information and interaction. Its potential to extend teaching beyond the classroom has been reported by many studies [1].

Basketball courses are an integral part of the higher education curriculum in China, and most of them are still taught in the traditional mode of face-to-face learning on the sportsground. Face-to-face teaching has its own undeniable advantages, such as hands-on practice, active interaction, close supervision and timely communication and correction, which are crucial to effective basketball teaching and skill learning. However, face-to-face teaching also has many limitations. Traditionally the teacher has been the "sage" on the sportsground, explaining and demonstrating the skills, techniques and movements. This has taken up most of the in-class time, leaving students with little time to practise and reflect on what they have been taught. At the same time,

Teaching Reform Grant of Tsinghua University in 2017 "Research into the Effectiveness of Mobile App Supported Blended Learning Approach to Reforming Basketball Curriculum. (Project No. ZY01_01). teachers find it hard to cater for individual students' needs due to insufficient in-class time [2]. This research reports and discusses a blended learning approach to meeting these challenges.

\section{LITERATURE REVIEW}

Blended learning has fast become more or less normalized in higher education in the past few years. Its effectiveness in improving students' learning has been evidenced in numerous studies [3-5]. Flipped classrooms, as one form of blended learning, have also gained increasing attention and have been used to transform curricula in different disciplinary areas including physical education. Research into the use of flipped classrooms in physical education has provided evidence supporting the effectiveness of this approach in terms of improved sports skill acquisition as more class time could be devoted to individualized instructions and hands-on practice. In addition, students' out-of-class learning and practice are supported by a variety of technology such as mini-video lectures and online discussion and reflection [6]. There are also studies reviewing the literature of the use of the flipped classroom approach and expositing the feasibility and advantages of this approach in improving basketball teaching [7-9].

However, the research on the effective design and evaluation of flipped basketball teaching is still scarce. To the best of our knowledge, no research has been done on using mobile apps to support the flipped classroom approach as far as basketball teaching is concerned. This paper attempts to fill in this gap by designing and evaluating a flipped basketball course in a university in China.

\section{RESEARCH QUESTIONS AND METHODS}

\section{A. Research Questions}

The following two research questions informed this study:

- In what ways can blended learning be designed in university basketball teaching?

- What are the students' perceptions of their blended learning experiences?

\section{B. Course Design: a Blended Learning Approach}

Informed by established blended learning design theories and principles [10], this research redesigned the contents and pedagogical approaches for each weekly 
learning module and developed a mobile app containing the contents of all the modules. This app was integrated into a learning management system called UMOOC that can be accessed by students anytime and anywhere via smartphones. Table I presents an example of the module design of a second year basketball course at a university in China.

TABLE I. AN EXAMPLE OF BLENDED LEARNING MODULE DESIGN

\begin{tabular}{|c|c|}
\hline Module & Key knowledge point and online learning requirement \\
\hline \multirow{8}{*}{$\begin{array}{l}\text { Module } \\
8\end{array}$} & 【Module Guide】 \\
\hline & $\begin{array}{l}\text { 1. Before class learning: viewing the videos and } \\
\text { completing the readings for this module; } \\
\text { 2. In-class: practice and problem solving; } \\
\text { 3. After class: reflection and discussion in the } \\
\text { discussion forum }\end{array}$ \\
\hline & 【Illustration through graphics】 \\
\hline & $\begin{array}{l}\text { Competency training: methods of increasing endurance } \\
\text { Knowledge building: violation of rules (travelling) }\end{array}$ \\
\hline & 【Video demonstration 】 \\
\hline & $\begin{array}{l}\text { Skills to be learned: holding ball break by cross-over step; two- } \\
\text { three zone offense }\end{array}$ \\
\hline & 【Reflection and discussion】 \\
\hline & $\begin{array}{l}\text { Reflecting and discussing what you have learned in this module } \\
\text { on the discussion forum. }\end{array}$ \\
\hline
\end{tabular}

The course design exemplified in Table I blends online learning with face-to-face in-class learning using the flipped classroom approach. This approach enabled students to learn the basic basketball rules, techniques and skills before coming class, freeing the in-class time for problem solving, individual guidance and hands-on practice. Reflection and discussion were also designed into the course to further consolidate student learning. Table II further illustrates this blended learning approach.

TABLE II. MOBILE APP-BASED BLENDED LEARNING APPROACH TO BASKETBALL TEARCHING

\begin{tabular}{|c|c|c|c|}
\hline & Before class & In class & After class \\
\hline $\begin{array}{c}\text { The } \\
\text { students }\end{array}$ & $\begin{array}{l}\text { - Go through } \\
\text { study guide } \\
\text { - Go through } \\
\text { self-learning } \\
\text { materials } \\
\text { - View video } \\
\text { lectures } \\
\text { - discuss and } \\
\text { share with } \\
\text { peers }\end{array}$ & $\begin{array}{l}\text { - Understanding } \\
\text { key/complex } \\
\text { points } \\
\text { - Hands-on } \\
\text { practice }\end{array}$ & $\begin{array}{l}\text { - Revision } \\
\text { - Reflection }\end{array}$ \\
\hline $\begin{array}{c}\text { The } \\
\text { teacher }\end{array}$ & $\begin{array}{l}\text { - Upload course } \\
\text { instructions } \\
\text { - Send out } \\
\text { announcement } \\
\text { - Online monitor } \\
\text { student learning } \\
\text { progress }\end{array}$ & $\begin{array}{l}\text { - Problem } \\
\text { solving } \\
\text { - Individualized } \\
\text { instruction }\end{array}$ & $\begin{array}{l}\text { - Answer } \\
\text { students' } \\
\text { questions } \\
\text { - Provide } \\
\text { feedback } \\
\text { - Adjust } \\
\text { teaching } \\
\text { plan }\end{array}$ \\
\hline
\end{tabular}

\section{Procedure and Participants}

The participants in this study were second year students from a male basketball course for special purposes. The new course design was first trialed in the spring semester of 2017 with four classes. There were 144 participants in total with 30-40 students to each class. The semester ran for 16 weeks with the traditional lecture-based teaching conducted in the first 7 weeks, and the blended learning approach was introduced and experimented in weeks 8-10. The rationale was two-fold: 1) students could compare the differences between traditional teaching and blended learning, and 2) the three weeks of blended learning could be used as a preparation for the full scale implementation in the following semester, the autumn semester.

In the autumn semester, the total participants reached 260, being students from 8 classes and including the 144 participants in the spring semester,. Blended leaning was in full operation between weeks 2-16.

\section{Data Colletion and Analysis}

There were two rounds of data collection using a mobile app-based survey instrument, calling voluntary participation from all students in the course. No incentives were offered for completing the surveys. The aim of the survey was to collect data regarding student satisfaction with the blended learning approach. In the spring semester in 2017, 109 surveys were collected in week 11 with a return rate of $75.60 \% .192$ surveys were collected in week $17-18$ in the following semester with a return rate of $73.85 \%$. A total of 301 surveys were collected for this research.

The survey contains 8 questions adapted from Arbaugh [11]. Arbaugh's survey was originally designed to assess student satisfaction with an online MBA course and has also been adopted in other relevant studies [12]. We translated 8 relevant questions into Chinese with wording modified to specifically compare the traditional and blended modes of delivery. For example, the original question from Arbaugh, "The quality of class discussions was high throughout the course" was modified as "In comparison to the traditional mode of teaching, the new approach improves in-class instructions and communication in genera" (see Table III and Table IV for all the survey questions used in this research). Likert scale was used to assess student satisfaction with ratings from 5-1, representing strongly agree, agree, neutral, disagree and strongly disagree.

The data was processed using SPSS. As determined by the research questions of this study, only the percentage of each rating was calculated to evaluate student satisfaction.

\section{RESULTS AND DISCUSSION}

\section{A. Results Answering the First Research Question- Blended Learning Design Principles}

As shown in Table I and II, the blended learning design in this course focused on extending learning to outside class, both before and after class. At the same time, the design also ensured that outside-class learning was adequately supported by a range of learning resources (e.g., video lectures, graphic illustrations) and interaction on the discussion forum, between the teacher and peers. The design also catered students' needs for flexibility in learning as the mobile app provided students with an easy access to learning materials anywhere and anytime.

The effectiveness of this approach was confirmed by the great majority of students, especially students in the autumn semester of 2017 as they believed that the new approach 
better met their learning needs (Q3: 78.65\%), improved inclass instruction and interaction (Q4: 77.08\%) as well as learning quality as a whole (Q1: 85.93\%). The great majority of the respondents were satisfied with learning with a mobile app (Q2: 84.28\%), and with this new approach (Q6:

$81.77 \%$ ). To further assess students' perception of the blended learning approach, we added two more questions in the second survey. In regarding to the usefulness of the video lectures in the mobile app, $70.83 \%$ agreed that they helped them practise basketball skills and techniques, and prepare for assessments (Q9). These video lectures were also highly valued by the students for its facilitation of group discussions (Q10: 92.71\%).

There was a small percentage in both surveys $(23.85 \%$, $23.44 \%$ respectively) of Agree in the answers to Question 8, which asks if the new approach increased the difficulty level of learning. Although the percentage was not significant, it still suggests that learning with technology does not come naturally even for the so called "digital natives" [13]. Therefore, the issue of user-friendliness should still receive some degree of attention in blend learning design.

\section{B. Results Answering the Second Research Question- Student Satisfaction with the Course}

For ease of comparison of the two survey results and for ease of discussion, we combined the percentages for "strongly agree" and "agree" as one positive indicator (Agree) of student satisfaction. Similarly, the percentages for "strongly disagree" and "disagree" were also grouped together as one category representing a negative perception (Disagree). Table III summarizes the results from the spring survey and Table IV contains the autumn survey results.

TABLE III. RESULTS FROM THE SURVEY CONDUCTED IN THE SPRING

\begin{tabular}{|c|c|c|c|}
\hline \multicolumn{4}{|c|}{ SEMESTER OF 2017} \\
\hline Statements & Agree & Neutral & Disagree \\
\hline $\begin{array}{l}\text { 1. In comparison to the traditional } \\
\text { mode of teaching, the new approach } \\
\text { improves the quality of learning }\end{array}$ & $66.97 \%$ & $28.44 \%$ & $4.59 \%$ \\
\hline $\begin{array}{l}\text { 2. In comparison to the traditional } \\
\text { mode of teaching, I have been more } \\
\text { satisfied the new way of learning } \\
\text { using a mobile app. }\end{array}$ & $69.72 \%$ & $22.94 \%$ & $7.34 \%$ \\
\hline $\begin{array}{l}\text { 3. In comparison to the traditional } \\
\text { mode of teaching, the new approach } \\
\text { better meets my learning needs. }\end{array}$ & $70.64 \%$ & $24.77 \%$ & $4.59 \%$ \\
\hline $\begin{array}{l}\text { 4. In comparison to the traditional } \\
\text { mode of teaching, the new approach } \\
\text { improves in-class instructions and } \\
\text { communication in general. }\end{array}$ & $56.88 \%$ & $33.03 \%$ & $10.09 \%$ \\
\hline $\begin{array}{l}\text { 5. The online learning using mobile } \\
\text { app in the new approach is important } \\
\text { for my learning improvement. }\end{array}$ & $59.63 \%$ & $29.36 \%$ & $11.01 \%$ \\
\hline $\begin{array}{l}\text { 6. In comparison to the traditional } \\
\text { mode of teaching, I have been more } \\
\text { satisfied with the new approach. }\end{array}$ & $66.06 \%$ & $26.61 \%$ & $7.55 \%$ \\
\hline $\begin{array}{l}\text { 7. I am more willing to choose PE } \\
\text { courses offered in this new approach } \\
\text { in the future. }\end{array}$ & $55.96 \%$ & $33.94 \%$ & $10.09 \%$ \\
\hline $\begin{array}{l}\text { 8. In comparison to the traditional } \\
\text { mode of teaching, the new approach } \\
\text { has increased the difficulty level of } \\
\text { my learning. }\end{array}$ & $23.85 \%$ & $31.19 \%$ & $44.95 \%$ \\
\hline
\end{tabular}

As shown in Table III, overall, students were satisfied with the new approach implemented in weeks 8-10 in the spring semester in 2017 , although the intervention only lasted for 3 weeks. This is evidenced in the percentages Agree, which ranges between $56.88 \%$ to $70.65 \%$ for the first seven questions.

TABLE IV. RESULTS FROM THE SURVEY CONDUCTED IN THE AUTUMN SEMESTER OF 2017

\begin{tabular}{|c|c|c|c|}
\hline Statements & Agree & Neutral & Disagree \\
\hline $\begin{array}{l}\text { 1. In comparison to the traditional } \\
\text { mode of teaching, the new approach } \\
\text { improves the quality of learning }\end{array}$ & $85.93 \%$ & $11.98 \%$ & $2.08 \%$ \\
\hline $\begin{array}{l}\text { 2. In comparison to the traditional } \\
\text { mode of teaching, I have been more } \\
\text { satisfied the new way of learning } \\
\text { using a mobile app. }\end{array}$ & $84.38 \%$ & $13.54 \%$ & $20.83 \%$ \\
\hline $\begin{array}{l}\text { 3. In comparison to the traditional } \\
\text { mode of teaching, the new approach } \\
\text { better meets my learning needs. }\end{array}$ & $78.65 \%$ & $19.79 \%$ & $1.56 \%$ \\
\hline $\begin{array}{l}\text { 4. In comparison to the traditional } \\
\text { mode of teaching, the new approach } \\
\text { improves in-class instructions and } \\
\text { communication in general. }\end{array}$ & $77.08 \%$ & $20.83 \%$ & $2.08 \%$ \\
\hline $\begin{array}{l}\text { 5. The online learning using mobile } \\
\text { app in the new approach is important } \\
\text { for my learning improvement. }\end{array}$ & $67.71 \%$ & $29.17 \%$ & $3.13 \%$ \\
\hline $\begin{array}{l}\text { 6. In comparison to the traditional } \\
\text { mode of teaching, I have been more } \\
\text { satisfied with the new approach. }\end{array}$ & $81.77 \%$ & $16.15 \%$ & $2.08 \%$ \\
\hline $\begin{array}{l}\text { 7. I am more willing to choose PE } \\
\text { courses offered in this new approach } \\
\text { in the future. }\end{array}$ & $70.83 \%$ & $25.52 \%$ & $3.65 \%$ \\
\hline $\begin{array}{l}\text { 8. In comparison to the traditional } \\
\text { mode of teaching, the new approach } \\
\text { has increased the difficulty level of } \\
\text { my learning. }\end{array}$ & $23.44 \%$ & $23.44 \%$ & $53.13 \%$ \\
\hline $\begin{array}{l}\text { 9. The video lectures in the App have } \\
\text { provided convenience for group } \\
\text { discussions. }\end{array}$ & $83.85 \%$ & $13.54 \%$ & $2.60 \%$ \\
\hline $\begin{array}{l}\text { 10. The video lectures in the App can } \\
\text { help me revise all the basketball skills } \\
\text { and techniques I have learned, and } \\
\text { help with my preparation for } \\
\text { assessment tasks. }\end{array}$ & $92.71 \%$ & $67.71 \%$ & $0.52 \%$ \\
\hline
\end{tabular}

Table IV demonstrates that the level of student satisfaction with the new approach was greatly improved in the autumn semester, as shown in the higher percentages for Agree across all the first seven questions in the survey, an increase by $8 \%$ to $23 \%$. The extended period of time in the autumn semester ( 15 weeks vs 3 weeks) for the implementation of the blended learning approach could be the key reason for the increased level of satisfaction. In the autumn semester, the students had more opportunities to experience the benefits of blended learning, and to see the improvements in their learning. This can be best explained by the $23 \%$ increase of Agree in the autumn survey in the answers to the statement that the new approach improves learning quality in comparison to the traditional mode of learning.

Question 8 seeks students' perspective from a different angle, stating that the new approach increased the difficulty level of their learning. The answer of Disagree increased by more than $8 \%$ in comparison to that in the spring survey $(53.13 \%$ vs $44.95 \%)$, suggesting a more positive attitude toward the new approach.

\section{CONCLUSION}

This research explored the needs for the transformation of basketball teaching in higher education, and proposed 
some design principles for integrating blended learning into the basketball curriculum. This blended learning approach supported by flipped classrooms and a mobile app was proven to be a desirable design approach and principle. Its pedagogical value is clearly evidenced in its effectiveness in extending mastery-based learning beyond the sportsgrounds through various forms of learning support, such as video lectures, group discussions and reflection in the Discussion Forum. As a result, this approach allowed the teacher more in-class time for individualized instructions and students had more in-class time to practice the newly learned skills and techniques under the guidance of the teacher. More lively interaction and effective communication were also happening in class. This was further attested by the students, as the data from the 301 surveys suggest a high level of student satisfaction with this approach and the course.

We recognize that these conclusions were drawn on the data collected from only one basketball course. Their applicability to other physical education courses in higher education needs to be further investigated. Nevertheless, this research provides a useful reference and direction for transforming the curriculum through blended learning in physical education.

\section{REFERENCES}

[1] G. Hwang, and C. Tsai, "Research trends in mobile and ubiquitous learning: a review of publications in selected journals from 2001 to 2010," British Journal of Educational Technology, 42(4), 2011.

[2] G. Wang, and J. Zhan, "Flipped classrooms in physical education: exploring the adaptive value, implementation and strategies," [in Chinese: 翻转课堂引入体育教学的价值及实施策略研究], Journal of Beijing Sport University, 39(2), 2016, pp.104-110.

[3] Y. Wang, X. Han, and J. Yang, "Revisiting the Blended Learning Literature: Using a Complex Adaptive Systems Framework," Educational Technology \& Society,18 (2), 2015, pp.380-393.

[4] X. Han, Y. Wang, T. Zhang, and J. Cheng (Eds.), Preparing for the Digital University: A review of the history, current state of distance, blended and online learning - translation, review and further research. Beijing, China: Tsinghua University Press, 2016.

[5] D. R. Garrison, and H. Kanuka, "Blended learning: Uncovering its transformative potential in higher education," The internet and higher education, 7(2), 2004, pp.95-105.

[6] P. Li, and L. Wang, "Opportunities and challenges: flipped classrooms in physical education in Chinese higher education," [in Chinese: 机遇与挑战——翻转课堂对我国高校体育教学的启示], Journal of Nanjing Sport University (natural science version),14(4), 2015, pp.122-128.

[7] C. Zhang, and Y. Bai, "Examining flipped classrooms implemented in the basketball courses," [in Chinese:试论翻转课堂在高校篮球教学 中的运用], Contemporary Sports Science, 5(20), 2015, pp.115-116.

[8] X. Zhu, "Appling flipped classrooms in the basketball classrooms in higher education,” [in Chinese: 翻转课堂教学在高校篮球课堂中的 应用], Contemporary Sports Science, 6(5), 2016, pp.38-39.

[9] Z. Zhao, and X. Xin, "An empirical study of the feasibility of implementing flipped classrooms in basketball education in higher education," [in Chinese: 翻转课堂在普通高校篮球教学中的可行性 分析及应用研究], Asia-Pacific Education, (9), 2016, p80.

[10] K. He, "New development of educational technology through blending learning: Volume I and II,”[in Chinese:看教育技术理论的 新发展：上、下], China Audio-Visual Education, 3(4), 2004, pp.16.

[11] J. B. Arbaugh, "Virtual classroom characteristics and student satisfaction with Internet-based MBA courses," Journal of Management Education, 24(1), 2000, pp.32-54.

[12] G. Cui, X. Han, and S. Wang, "Online learning satisfaction: the factors of students' control group tendency and other individual differences," [in Chinese: 学生控制源倾向及其它个体差异对在线
学习满意度的影响], China Audio-Visual Education, 331(8), 2014, pp.55-61.

[13] J. Palfrey, and U. Gasser, Born digital: understanding the first generation of digital natives. New York: Basic Books, 2008. 